\title{
Understanding Corporate Rebranding: An Evolution Theory Perspective
}

\author{
Alexander C. Tevi ${ }^{1}$ \& Olutayo Otubanjo ${ }^{2}$ \\ ${ }^{1}$ School of Media and Communication, Pan-African University, Lagos, Nigeria \\ ${ }^{2}$ Lagos Business School, Pan-African University, Lagos, Nigeria \\ Correspondence: Alexander C. Tevi, School of Media and Communication, Pan-African University, 3, Ahmed \\ Onibudo St., Victoria Island, Lagos, Nigeria. Tel: 234-802-300-2328. E-mail: alexander.tevi@smc.edu.ng
}

Received: January 3, 2013

Accepted: February 16, 2013 Online Published: April 15, 2013

doi:10.5539/ijms.v5n3p87

URL: http://dx.doi.org/10.5539/ijms.v5n3p87

\begin{abstract}
This paper seeks to create an epistemologically grounded understanding of the causes and process of corporate rebranding via the lens of the theory of evolution by natural selection. A review of the factors that trigger corporate rebranding, as reported in academic literature, is made. Following the review, a case is made for the absence of an epistemologically grounded understanding of why firms rebrand. Consequently, the theory of evolution by natural selection is brought forward as a platform for the development of a new model that explicates the causes and process of corporate rebranding. A new model anchored on the theory of evolution by natural selection, and a new definition of corporate rebranding is advanced. Essentially, the model offers epistemologically grounded reasons for ascendancy of corporate rebranding in the environment. This is a conceptual paper - meaning that the model suggested in this study is yet to be subjected to a serious empirical exercise. The review of literature indicates the absence of an epistemologically grounded understanding of the causes and process of corporate rebranding in the business environment. The pursuit of this exercise therefore makes this work original, unique and valuable.
\end{abstract}

Keywords: corporate rebranding, brand equity, evolution theory, natural selection, corporate body, environment, genes, recombination \& organism

\section{Introduction}

A variety of studies have addressed the factors that trigger the rebranding of business organizations (see for instance Olins, 1995; Baker \& Balmer, 1997; Balmer \& Dinnie, 1999; Kaikati, 2003; Stuart \& Muzellec, 2004; Muzellec, 2006). Unfortunately nearly all of these examined the causes of rebranding passively and parenthetically, without a comprehensive study of its causes. More importantly, the majority of these works offer no epistemological rationale as to why these changes occur. Given the absence of literature in this regard, this paper sets out to provide a comprehensive analysis of the factors that drive rebranding exercises - anchored firmly on the theory of evolution by natural selection.

This paper has been divided into five parts, and this introductory section constitutes the first. The second part examines various works concerning the causes of rebranding. The third part discusses the theory of evolution by natural selection and how it offers a strong foundation for an understanding of the factors that drive the rebranding of business organizations. Part four explains the process and meaning of corporate rebranding from the perspective of evolution theory. Part five concludes the study by discussing the findings that emerge in this study.

\section{Review of Literature: Causes of Rebranding}

The causes of corporate rebranding can be summarised under two main umbrellas, namely internal and external causes (Goi \& Goi, 2011). Under internal causes, factors such as changes within the structure of business organizations (Lomax, Mador \& Fitzhenry, 2002), the need for a new image (Gambles \& Schuster, 2003) and the desire to upgrade a firm's personality in the minds of consumers and other stakeholders play a critical role in understanding the reasons why business organizations engage in rebranding. Please see other internal drivers in Goi and Goi (2011). With reference to external factors, Goi and Goi (2011) contend that issues such as competitiveness, perception of external stakeholders, economic slowdown, shifts in marketplace and so on 
constitute the critical external factors that drive the rebranding of business organizations. Table 1, adapted from

Goi and Goi (2011) gives further clarification.

Table 1. Causes of rebranding

\begin{tabular}{|c|c|c|c|c|c|c|c|c|}
\hline Authors & $\begin{array}{l}\text { Boyle } \\
(2002)\end{array}$ & $\begin{array}{l}\text { Lomax et al } \\
(2002)\end{array}$ & $\begin{array}{l}\text { Gambles and } \\
\text { Schuster } \\
(2003)\end{array}$ & $\begin{array}{l}\text { Kaikati and } \\
\text { Kaikati } \\
(2003)\end{array}$ & $\begin{array}{l}\text { Rosenthal } \\
(2003)\end{array}$ & Causon (2004) & $\begin{array}{l}\text { Stuart and } \\
\text { Muzellec (2004) }\end{array}$ & $\begin{array}{l}\text { Muzellec and } \\
\text { Lambkin } \\
(2006)\end{array}$ \\
\hline $\begin{array}{l}\text { Internal } \\
\text { drivers }\end{array}$ & & $\begin{array}{l}\text { Corporate } \\
\text { structural } \\
\text { change }\end{array}$ & $\begin{array}{l}\text { Changes in } \\
\text { the image of } \\
\text { the service }\end{array}$ & & Upgrading & $\begin{array}{l}\text { Unite the } \\
\text { organization } \\
\text { behind one brand. } \\
\text { Align the culture. } \\
\text { Re-establish and } \\
\text { re-energize } \\
\text { position. Embed } \\
\text { the new vision, } \\
\text { mission and } \\
\text { values }\end{array}$ & $\begin{array}{l}\text { Mergers. } \\
\text { Acquisitions and } \\
\text { divestitures, } \\
\text { Image is } \\
\text { out-dated. New } \\
\text { focus or vision. } \\
\text { New socially } \\
\text { responsible image. }\end{array}$ & $\begin{array}{l}\text { Change in } \\
\text { ownership } \\
\text { structure. } \\
\text { Change in } \\
\text { corporate } \\
\text { strategy. }\end{array}$ \\
\hline $\begin{array}{l}\text { External } \\
\text { drivers }\end{array}$ & $\begin{array}{l}\text { Increasing } \\
\text { disturbance } \\
\& \\
\text { competitive } \\
\text { environment }\end{array}$ & $\begin{array}{l}\text { Concern } \\
\text { over external } \\
\text { perceptions } \\
\text { of the } \\
\text { organization } \\
\text { and its } \\
\text { activities }\end{array}$ & & $\begin{array}{l}\text { Economic } \\
\text { slow down }\end{array}$ & & & $\begin{array}{l}\text { Shifts in the } \\
\text { marketplace. } \\
\text { Change in the } \\
\text { economic and } \\
\text { legal conditions. }\end{array}$ & $\begin{array}{l}\text { Change in } \\
\text { external } \\
\text { environment. } \\
\text { Change in } \\
\text { competitive } \\
\text { position. }\end{array}$ \\
\hline
\end{tabular}

Culled from Goi and Goi (2011)

Whilst Goi and Goi's (2011) work and others (see Boyle, 2002; Lomax et al, 2002; Gambles \& Schuster, 2003; Kaikati \& Kaikati, 2003; Rosenthal, 2003; Causon, 2004; Stuart \& Muzellec, 2004; Muzellec \& Lambkin, 2006) give a broad understanding of the causes of corporate rebranding, there remains no logical epistemological understanding of the reasons these changes occur. Given this argument, an attempt is made in the next section to provide an epistemological logic that could further create an understanding of the reasons businesses engage in rebranding.

\section{Darwin's Theory of Evolution by Natural Selection}

Darwin's theory of natural selection states that the observable characteristics of a trait in an organism (phenotype) are determined by an interaction between genes (genotype) and the environment in which the genes exist. The environment influences the expression of genes. Genes carry the information that expresses a trait. The environment of genes includes the molecular biology in its cell, other cells, other individuals, populations, species, as well as the abiotic environment. In sexual reproduction, there is a reshuffling of the genes responsible for a trait. This results in each offspring having a different combination of the same set of genes responsible for a particular trait. This reshuffling is called recombination. Usually the offspring expressing a particular combination of the genes controlling a trait is more favoured by the environment than others. Over time, the offspring with the variant that is more favoured by the environment survives and reproduces more than the offspring with other variants of the same trait. The offspring with the variant that is more favoured by the environment gradually takes over, and the offspring with other variants gradually become extinct. This way, the population evolves. This process is called Natural Selection. It is the main adaptive form of evolution. It is different from Artificial Selection, where man is responsible for the reproduction advantage of a variant of a trait over others (Wikipedia).

\subsection{Fusing Darwin's Theory of Evolution by Natural Selection into Corporate Rebranding}

A corporation is a form of an organism. Just as a corporate body consists of different departments and specializations, an organism consists of systems and organs. Genes are responsible for the physical expressions of an organism. In the case of corporate bodies, it is values. This is why a brand is defined as a cluster of functional and emotional values that enable a promise to be made about a unique and welcomed experience (de Chernatony, 2010). Each experience is a manifestation of the brand to the customer. Corporate brands are 
expressions of a combination of values. The unique combinations of values give corporate brands their unique identities, just as genes organisms. Rokeach (1973) defines a value as "an enduring belief that a specific mode of conduct or end-state of existence is personally or socially preferable to an opposite or converse mode of conduct or end-state of existence". Values dictate the physical manifestations and behaviours of brands, which is brand identity.

Taking the correspondences between an organism and a corporate body further, evolution by natural selection in organisms is akin to rebranding in corporate organizations. Evolution by natural selection shows that environment influences the observable expressions of genes and also 'selects' particular heritable traits for survival. The environment of genes includes the cell in which it exists and other matter exterior to it (see definition). This corresponds with the internal and external factors that influence a corporate brand. They influence the creation and expression of values. Corporate rebranding therefore is a continuous recombination of values or their extensions in an attempt to be selected for survival by the environment; the most important of which are the customers. Only brands continuously chosen by customers survive. The ultimate goal of the corporate rebranding phenomenon is to survive and thrive; same with natural selection by evolution. Organisms adapt to an environment through evolution by natural selection; corporate brands adapt to their environment by corporate rebranding.

\subsection{External and Internal Environment: Stimuli for Corporate Rebranding}

As earlier defined, the environment of genes includes the molecular biology in its cell, other cells, other individuals, populations, species, as well as the abiotic environment. This clearly shows that the environment of an organism is both internal and external to it. The causes of evolution by natural selection are, therefore, within and outside an organism. By analogy, the causes of rebranding should also be within and outside a corporate body. This confirms Goi and Goi's (2011) summary of the causes of corporate rebranding.

\subsection{The Development of Conceptual Frameworks of Evolutionary and Revolutionary Rebranding}

Based on the knowledge that rebranding has its roots in the environment, two conceptual frameworks have been developed for the study of the phenomenon. However, evolutionary rebranding has been treated differently from revolutionary rebranding. This is because each has a different goal. The goal of evolutionary rebranding is to build on the equity of the one and same corporate organization, while the goal of revolutionary rebranding is to transfer previous equity and build a completely new one altogether. The frameworks are discussed below:

\subsubsection{The Evolutionary Rebranding Framework}

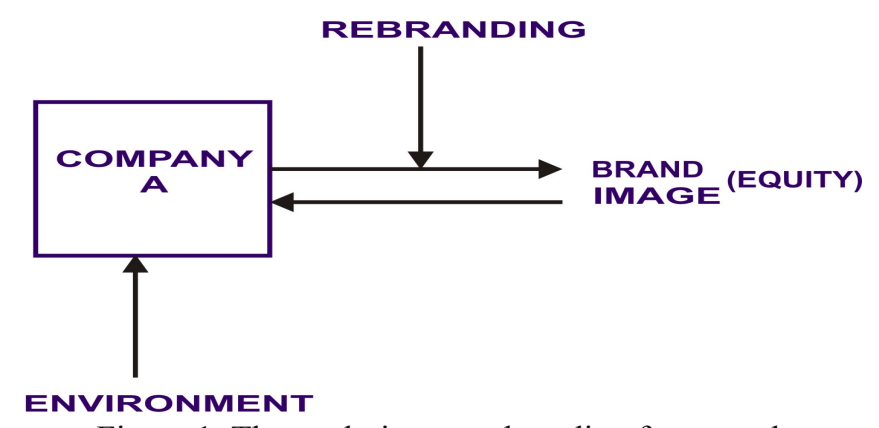

Figure 1. The evolutionary rebranding framework

Source: developed by authors

Evolutionary rebranding framework is a two-way process, which requires getting constant feedbacks from stakeholders. Its only goal is to create desired image in the minds of stakeholders. Figure 1 gives a graphic illustration of the evolutionary rebranding framework 


\subsubsection{The Revolutionary Rebranding Framework}

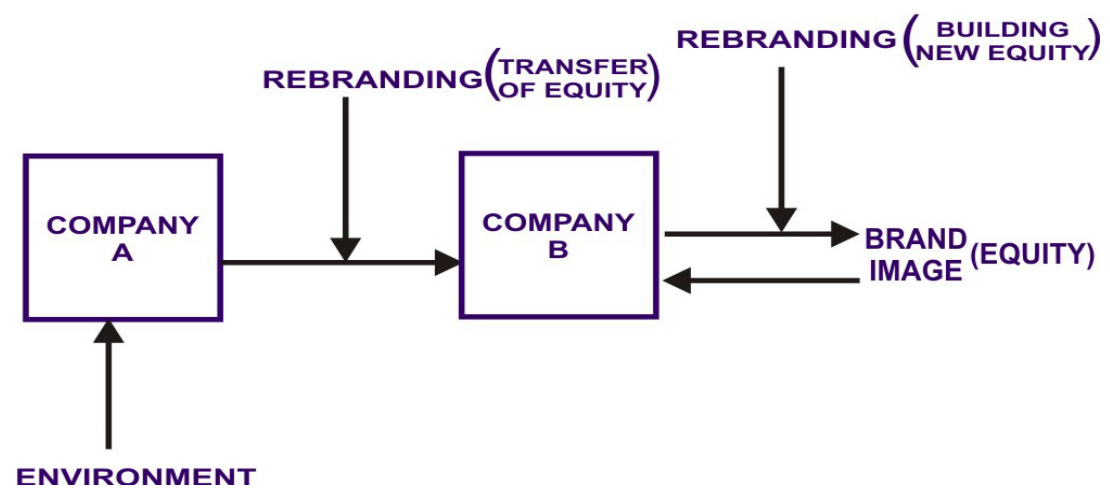

Figure 2. The revolutionary rebranding framework

Source: developed by authors

This framework consists of two parts; the first is a successful transfer of the equity of the previous company, and the second part is the building of an entirely new image and equity. Tevi (2013) reported that subscribers continued calling a telecommunications network by its previous names, long after its multiple rebranding. Muzellec and Lambkin (2006) also emphasized that rebranding takes time, and that it's a continuous exercise. The second part of revolutionary rebranding is very much like the evolutionary rebranding process.

\section{The Impact of the Theory of Evolution on Existing Corporate Rebranding Models}

Muzellec and Lambkin's (2006) model made significant contributions to the understanding of corporate rebranding. The model gives a clear goal for every corporate rebranding exercise. Without a goal, the whole process of corporate rebranding will be desultory. The model emphasises the need to know the causes of rebranding. The cause of rebranding guides the course of its process. The model also makes it clear that rebranding is first and foremost an internal process. All of these have strong basis in the theory of evolution by natural selection. However, Muzellec and Lambkin (2006) failed to look at the causes of corporate rebranding from a theoretical perspective. Theoretically, all causes of corporate rebranding come from the environment in which a brand operates; the changes in identity, and subsequently image, is for the organization to survive and thrive; and, the process of rebranding is critically internal to the organization. If the traits of an organism do not consist of a combination of genes favoured by its environment, that organism cannot survive and thrive in that environment. Therefore, the Muzellec and Lambkin's (2006) model approximates the corporate rebranding phenomenon, but it lacks a theoretical backing that puts it in clearer perspective.

[Lomax et al's (2002) working paper also addresses the need to know the cause of corporate rebranding and the purpose of the whole process. The model delves into the strategic management details of the process of rebranding. However, it fails to address the process itself. A process is a sequence of events on how development and change unfold and conceptualised as a succession of events, stages, cycles, or states in the development of an organization (Van de Ven and Poole 2005). Lomax et al's (2002) model of rebranding does not address the sequence or succession of stages that rebranding involves. Rather, it focuses on the management of the process. It also fails to incorporate the causes of rebranding and to direct the process to a clear goal. Theoretically, it is baseless.

Juntenen, Saraniemi \& Jussila (2009), who would rather focus on the process of rebranding, leave out the cause of rebranding, which is crucial to the understanding and execution of the whole process. Juntunen et al's (2009) model incorporates people and communication. It derails from its focus on process. Processes are about what is to be done, and how it is to be done, but not on who is to get it done. Regarding what is to be done, Muzellec, Doogan \& Lambkin (2003) identified four phases in the heart of rebranding proper: re-positioning, re-naming, re-designing and re-launching. For these four stages, all the terms used are germane to marketing to and all the professions involved in the rebranding process. Juntunen et al (2009) used generalised terms to enumerate their stages of rebranding. These terms carry neither connotations of professional understanding nor executional peculiarities to marketing and marketing communications. They have no place in branding lexicon. The Juntunen et al (2009) and Muzellec et al (2003) models have no basis in theory. 
Merilees and Miller (2008) developed six principles of rebranding from four case studies. They tested and confirmed these principles in a fifth case study. Of the six principles, only the ones concerning stakeholders have a solid place in the general rebranding process. The rest are only true to particular situations of rebranding. Moreover, the principles lead to no clear goal and do not accommodate the cause of rebranding. They lack an epistemological backing.

From the review of literature on the models of rebranding, it is obvious that none of the authors of the existing models of corporate rebranding premised their works on any theory. This, as has been argued, has implications for model construction. However, virtually all the models have relevant commonalities, and virtually all of them identified one or more salient stages which the theory of evolution by natural selection can explain. The salient stages will now be built into a model of rebranding (see figure 3) that stands on a solid theoretical base.

\subsection{The New Corporate Rebranding Model Based on Evolution Theory}
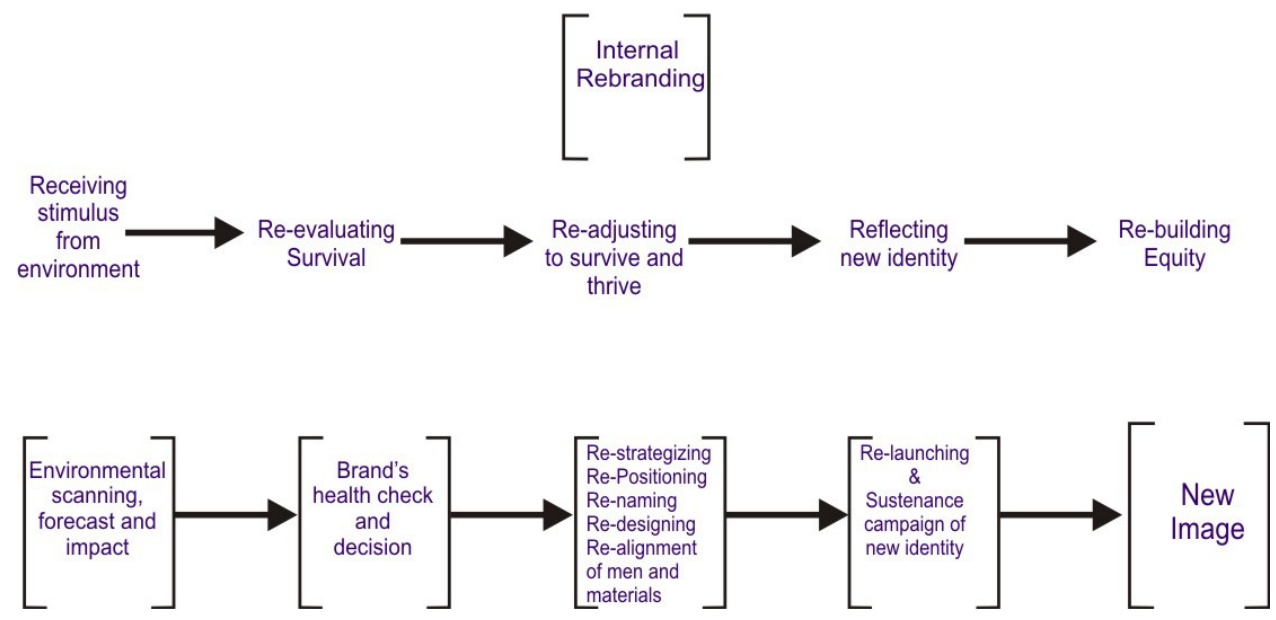

Figure 3. The new model of rebranding

Source: developed by authors

In order to survive and thrive, an organism has to express itself in traits that the environment will favour for selection. To be selected by customers, a corporate brand should look to its environment to know what it prefers. It will then do a check up, to know if the trait it expresses presently is favoured by the environment. If not, it will have to do a recombination of values and/or its expressions to achieve that which the environment will favour. Recombination is entirely internal to the organization. It is the stage of internal rebranding. Since the environment keeps changing business organizations too have to keep changing to survive in the environment. Based on this inverse application of the theory of evolution by natural selection, the new model of corporate rebranding is divided into five stages. One key feature this new model establishes clearly is that internal rebranding, which includes personnel re-alignment, is actually everything that is done for and within the organization to create a new identity for it. The model also shows that internal rebranding is a pre-requisite to the exposure of a new identity to all external stakeholders. The model also highlights the sub-processes at each stage, using terms well-known in marketing lexicon. This enables managers and other brand experts to know what is required of them at each stage of the rebranding process.

\subsection{Towards a New Meaning of Corporate Rebranding}

Until now, the meaning of corporate rebranding is sought solely on the basis of empirical research. No attempt has been made to define the phenomenon also from an epistemological perspective, whereas no definition can stand on either of these two legs alone. This paper attempts to combine the strong points from empirical evidence definitions with the insight from theoretical understanding. This it does by reviewing existing definitions in the light of the theory of evolution by natural selection.

\subsubsection{Re-Defining Corporate Rebranding}

Building on the definition of a brand by the American Marketing Association (AMA), Muzellec et al (2006) suggest that rebranding can be defined as the creation of a new name, term, symbol, design or a combination of 
them for an established brand with the intention of developing a differentiated (new) position in the minds of stakeholders and competitors. Also building on the definition of Einwiller and Will (2002) for corporate branding, Juntenen et al (2009) consider corporate rebranding as a systematically planned and implemented process of creating and maintaining a new favourable image and consequently a favourable reputation of the company as a whole by sending signals to all stakeholders and by managing behaviour, communication and symbolism in order to pro-act or react to change. Breaking away from the mould of adapting existing definitions, Merrilees and Miller (2008) propose that corporate rebranding is the "disjunction or change between an initially formulated corporate brand and a new formulation."

These definitions have one thing in common; they define a process based on empirical knowledge. They fail to look at the causative factor: the environment. They fail to also emphasize the theoretical perspective. With a realisation of the need to have a theoretically and empirically balanced perspective in literature, the authors submit this new definition:

Corporate rebranding is a continuing process whereby an organization responds to the dynamics in its business environment by changing its self-identity in order to survive and thrive.

Going by the biologic insight and analogy of rebranding, an organism announces its new identity by simply reflecting it. For this reason, no attempt has been made to accommodate the reflecting of a new identity in this new definition. It is assumed to be automatic in the whole process. In addition, the definition goes beyond the inclusion of brand image and equity as the main goal of corporate rebranding. This is because brand image and equity are not an end in themselves. They only serve to make the brand survive and thrive.

\section{Discussion and Conclusion}

This paper examines the causes of corporate rebranding from the perspective of the theory of evolution by natural selection. It confirms internal and external causes of rebranding as emanating from the business environment. Backed by this theory, this paper goes further to re-examine the existing models of corporate rebranding, and creates a new model. This is with the view that all rebranding exercises are caused by both the internal and external business environment in which an organization exists. Finally, it submits a new definition of rebranding that sits pretty on the tripod of empirical evidence, theoretical grounding and a new corporate rebranding model.

Eight findings emerge from this study. First, the theory of evolution by natural selection explains the corporate rebranding phenomenon. Second, it confirms that rebranding is caused by the external and internal business environment. Third, the paper developed a new model of the corporate rebranding process. Fourth, the new model constitutes internal rebranding as everything done within by staff and outside by hired experts for the sake of rebranding. Fifth, the new model confirms and makes clear the established notion that internal rebranding should be a pre-requisite to the exposure of new corporate self-identity. Sixth, the new model reveals the sub-processes that each stage of the rebranding process entails. Seventh, the study creates different frameworks for revolutionary and evolutionary rebranding. Eighth, the study submits a new definition of corporate rebranding, which states: Corporate rebranding is a continuing process whereby an organization responds to the dynamics in its business environment by changingits self-identity in order to survive and thrive.

The processes of corporate rebranding described in reviewed works (Boyle, 2002; Lomax et al 2002; Gambles \& Schuster, 2003; Kaikati \& Kaikati, 2003; Rosenthal, 2003; Muzellec et al 2003; Causon, 2004; Stuart \& Muzellec, 2004; Muzellec \& Lambkin, 2006, Juntunen et al 2009) can easily find expression in the new model developed. In addition, the model also explains multiple rebranding, a phenomenon Tevi (2013) reported. It also eradicates the notion of multiple corporate rebranding as being a different concept from corporate rebranding, because rebranding is a continuing process. The new definition, model and theory of corporate rebranding open a gap in literature: the need to test them against any new case of corporate rebranding.

\section{References}

American Marketing Association. (1985). Board approves new marketing definition. Marketing News, March 1, p.1.

Baker, M. J., \& Balmer, J. M. T. (1997). Visual identity: trappings or substance? European Journal of Marketing, 31(5/6), 366-382. http://dx.doi.org/10.1108/eb060637

Balmer, J. M. T., \& Dinnie, K. (1999). Corporate identity and corporate communications: the antidote to merger madness. Corporate Communications: An International Journal, 4(4), 182-192. 
Boyle, E. (2002). The Failure of Business Format Franchising in British Forecourt Retailing: A Case Study of the Rebranding of Shell Retail's Forecourts. International Journal of Retail \&Distribution Management, 30(5), 251-263. http://dx.doi.org/10.1108/09590550210426417

Causon, J. (2004). The Internal Brand: Successful Cultural Change and Employee Empowerment. Journal of Change Management, 4(4), 297-307. http://dx.doi.org/10.1080/1469701042000259631

Daly, A., \& Moloney, D. (2004). Managing Corporate Rebranding. Irish Marketing Review, 17(1/2), 30-36.

De Chernatony, L. (2010). From Brand Vision to Brand Evaluation: The Strategic Process of Growing and Strengthening Brand (3rd ed.). Elsiever, UK.

Einwiller, S., \& Will, M. (2002). Towards an integrated approach to corporate branding - an empirical study. Corporate Communications, 7(2), 100. http://dx.doi.org/10.1108/13563280210426160-

Gambles, B., \& Schuster, H. (2003). The Changing Image of Birmingham Libraries: Marketing Strategy Into Action. New Library World, 104(9), 361-371. http://dx.doi.org/10.1108/03074800310493189

Goi, C., \& Goi, M. (2011). Review on models and reasons of rebranding. International conference on social and humanity, IPEDR, 5. IACSIT Press, Singapore.

http://en Wikipedia.org/wiki/Evolution

http://en.wikipedia.org/wiki/Natural_selection

Juntenen, M., Saraniemi, S., \& Jussila, R. (2009). Corporate rebranding as a process. Proceedings of the 5th Thought Leaders Conference on Brand Management, 6th-7th April 2009, Athens, Greece.

Kaikati, J. G., \& Kaikati, A. M. (2003). A Rose by Any Other Name: Rebranding Campaigns That Work. Journal of Business Strategy, 24(6), 17-23. http://dx.doi.org/10.1108/02756660310509451

Lomax, W., Mador, M., \& Fitzhenry, A. (2002). Corporate rebranding: learning from experience. Ocassional Paper Series, No 48. Retrieved from http://business.Kingston.ac.uk/papers/opres48.pdf

Merrilees, B., \& Miller, D. (2008). Principles of corporate rebranding. European Journal of Marketing, 42(5/6), 537-552. http://dx.doi.org/10.1108/03090560810862499-

Muzellec, L. (2006). What is in a name change? Re-joycing Corporate Names to Create Corporate Brands. Corporate Reputation Review, 4(8), 305-316. http://dx.doi.org/10.1057/palgrave.crr.1540257

Muzellec, L., \& Lambkin, M. (2006). Corporate rebranding: destroying, transferring or creating brand equity? European Journal of Marketing, 40(7/8), 803-824. http://dx.doi.org/10.1108/03090560610670007

Muzellec, L., Doogan, M., \& Lambkin, M. (2003). Corporate rebranding: an exploratory review. Irish Marketing Review, 16(2), 31.

Olins, W. (1995). The New Guide to Identity. Gower Publishing, Aldershot, UK.

Rokeach, M. (1973). The nature of human values. New York: The Free Press.

Rosenthal, G. (2003). A Name by Any Other Name: Responding to Increasing Role of Marketing in Higher Education. Doctoral Dissertation, University of Pennsylvania.

Stuart, H., \& Muzellec, L. (2004). Corporate make-overs: can a hyena be rebranded. Journal of Brand Management, 11, 472-482. http://dx.doi.org/10.1057/palgrave.bm.2540193

Tevi, A. (2013). The effect of multiple rebranding on customer loyalty in Nigerian mobile telephony. InternationalJournal of Marketing Studies, 5(2), 120.

Van de Ven, A. H., \& Poole, M. S. (2005). Alternative approaches for studying organizational change. Organization Studies, 26(9), 1377-1404. http://dx.doi.org/10.1177/0170840605056907 